\title{
EFEKTIFITAS PERLINDUNGAN HUKUM TERHADAP ANAK MELALUI SARANA DIVERSI DALAM SISTEM PERADILAN PIDANA
}

\author{
Ismu Chaidir Makkarannu \\ Mahasiswa Program Pascasarjana Universitas Muslim Indonesia Makassar \\ email : chaidirismu@gmail.com
}

\begin{abstract}
The application of diversion as a form of settlement of child crime through restorative justice approach done in Makassar is less effective, as a result of various factors that influence both externally and internally namely: lack of investigators, prosecutors and judges who are certified specifically to solve the problem of crime by the Children, lack of understanding about diversity, less effective law enforcement, limited economic conditions for the children's family, and poor social environment.
\end{abstract}

Keywords : Legal Protection, Children; Divertion;

\section{Abstrak}

Penerapan pengalihan sebagai bentuk penyelesaian kejahatan anak melalui pendekatan keadilan restoratif yang dilakukan di Makassar kurang efektif, sebagai akibat dari berbagai faktor yang mempengaruhi baik secara eksternal maupun internal yaitu: kurangnya penyidik, jaksa dan hakim yang disertifikasi khusus untuk menyelesaikannya. masalah kejahatan oleh Anakanak, kurangnya pemahaman tentang keragaman, penegakan hukum yang kurang efektif, kondisi ekonomi yang terbatas untuk keluarga anak-anak, dan lingkungan sosial yang buruk.

Kata kunci: Perlindungan Hukum; Anak; Diversi;

\section{A. PENGANTAR}

Dalam Undang-Undang Dasar 1945 yang telah diamandemen secara tegas menyatakan bahwa dalam Pasal 28B ayat (2) yang berbunyi: "setiap anak berhak atas kelangsungan hidup, tumbuh, dan berkembang serta berhak atas perlindungan dari kekerasan dan diskriminasi”. Namun, kemajuan ilmu pengetahuan dan teknologi saat ini yang tidak terbendung dan sangat kompleks, turut mempengaruhi kemajuan dalam tumbuhkembang anak-anak Indonesia yang tentu saja tidak hanya berdampak positif semata-mata, melainkan juga dapat berdampak negatif. Berbagai tekanan hidup bisa jadi membuat generasi penerus bangsa ini, terjebak untuk melakukan hal-hal yang melanggar norma-norma yang selama ini hidup di dalam masyarakat.

Diversi merupakan pemberian kewenangan kepada aparat penegak hukum untuk mengambil tindakan-tindakan kebijaksanaan dalam menangani, atau menyelesaikan masalah pelanggar anak dengan tidak mengambil jalan formal, antara lain menghentikan atau tidak meneruskan/melepaskan dari proses peradilan pidana, atau mengembalikan/menyerahkan kepada masyarakat dan bentuk-bentuk kegiatan pelayanan sosial lainnya. Penerapan Diversi dapat dilakukan disetiap tingkat pemeriksaan, baik itu dilakukan oleh 
Penyidik, Penuntut Umum maupun oleh Hakim Anak. Hal tersebut dilakukan untuk mengurangi dampak negatif keterlibatan anak dalam proses peradilan tersebut.

Diversi sebagai proses pengalihan dari proses yustisial ke proses nonyustisial, bertujuan menghindarkan anak dari penerapan hukum pidana yang seringkali menimbulkan pengalaman yang pahit, berupa stigmatisasi (cap negatif) berkepanjangan, dehumanisasi (pengasingan dari masyarakat), dan menghindarkan anak dari kemungkinan terjadinya prisionisasi (pemenjaraan) yang menjadi sarana transfer kejahatan terhadap anak.

Sistem Peradilan Pidana Anak, adalah keseluruhan proses penyelesaian perkara anak yang berhadapan dengan hukum, mulai tahap penyelidikan sampai dengan tahap pembimbingan setelah menjalani pidana. Anak adalah anak yang telah berumur 12 (dua belas) tahun, tetapi belum berumur 18 (delapan belas) tahun yang diduga melakukan tindak pidana. Diversi, adalah suatu pengalihan penyelesaian kasus-kasus anak yang diduga melakukan tindak pidana tertentu, dari proses pidana formal ke penyelesaian damai antara anak yang melakukan tindak pidana dengan korban yang difasilitasi oleh keluarga dan/atau masyarakat, Pembimbing Kemasyarakatan Anak, Polisi, Jaksa atau Hakim.

Pendekatan restorative justice atau keadilan restoratif adalah pendekatan yang dilakukan dalam menyelesaikan perkara pidana Anak yang berpusat pada kebutuhan korban, pelaku kejahatan, dan masyarakat dengan lebih mementingkan pemulihan korban, pelaku kejahatan, dan masyarakat.

\section{B. ANALISIS DAN PEMBAHASAN}

Diversi dilaksanakan dengan tujuan antara lain: mencapai perdamaian antara korban dan anak, menyelesaikan perkara anak di luar proses peradilan, menghindarkan anak dari perampasan kemerdekaan, mendorong masyarakat untuk berpartisipasi, dan menanamkan rasa tanggung jawab kepada anak.

Diversi dilakukan melalui musyawarah dengan melibatkan anak dan orang tua/walinya, korban atau anak korban dan/atau orang tua/walinya, pembimbing kemasyarakatan, dan pekerja sosial profesional berdasarkan pendekatan Keadilan Restoratif, dan dalam hal diperlukan, musyawarah diversi dapat pula melibatkan tenaga kesejahteraan sosial dan/atau masyarakat.

Diversi dilaksanakan dengan memperhatikan hal-hal sebagai berikut: kepentingan korban, kesejahteraan dan tanggung jawab Anak, penghindaran stigma negatif, penghindaran pembalasan, keharmonisan masyarakat, dan kepatutan, kesusilaan dan ketertiban umum. Penyidik Anak, Penuntut Umum Anak dan Hakim Anak dalam melakukan diversi harus mempertimbangkan kategori tindak pidana, umur Anak, hasil penelitian kemasyarakatan dan dukungan lingkungan keluarga dan masyarakat.

Kesepakatan diversi dapat dilakukan tanpa persetujuan korban dan/atau keluarga Anak korban, dalam hal: tindak pidana yang berupa pelanggaran, tindak pidana ringan, tindak pidana tanpa korban, atau nilai kerugian korban tidak lebih dari nilai upah minimum provinsi setempat. 
Kesepakatan diversi dapat berbentuk: pengembalian kerugian dalam hal ada korban, rehabilitasi medis dan psikososial, penyerahan kembali kepada orang tua/wali, keikutsertaan dalam pendidikan atau pelatihan di lembaga pendidikan atau LPKS paling lama 3 (tiga) bulan, atau pelayanan masyarakat paling lama 3 (tiga) bulan.

Hasil kesepakatan diversi dituangkan dalam bentuk Surat Kesepakatan Diversi, dan surat tersebut kemudian dimintakan penetapan Ketua Pengadilan Negeri di wilayah tempat terjadinya perkara, atau wilayah tempat kesepakatan diversi dibuat.

Diversi dilakukan pada setiap tahap pemeriksaan dengan tata cara dan koordinasi sebagai berikut :

1. Tata cara dan koordinasi pelaksanaan diversi pada tahap penyidikan.

a. Setelah menerima laporan polisi, maka Penyidik Anak wajib bersurat untuk meminta saran tertulis dari petugas Pembimbing Kemasyarakatan/Bapas;

b. Hasil Penelitian Kemasyarakatan wajib diserahkan oleh petugas Pembimbing Kemasyarakatan/Bapas kepada Penyidik Anak dalam waktu paling lama 3 × 24 jam setelah permintaan Penyidik Anak diterima;

c. Penyidik Anak wajib mulai mengupayakan diversi dalam waktu paling lama 7 (tujuh) hari setelah penyidikan dimulaidalam hal perkara anak tersebut memenuhi syarat untuk dilakukan diversi;

d. Apabila pelaku maupun korban setuju untuk dilakukan diversi, maka Penyidik Anak/Fasilitator Diversi, Penasihat Hukum, Pembimbing Kemasyarakatan/Bapas, dan Pekerja Sosial memulai proses diversi melalui musyawarah diversi penyelesaian perkara dengan melibatkan pihak terkait;

e. Proses musyawarah diversi tersebut dilaksanakan paling lama 30 (tiga puluh) hari setelah dimulainya proses diversi;

f. Penyidik Anak / Fasilitator Diversi membuat Berita Acara Diversi;

Dalam hal diversi dinyatakan berhasil, maka prosedur selanjutnya adalah :

a. Apabila para pihak mencapai kesepakatan, maka hasil kesepakatan tersebut dituangkan dalam bentuk kesepakatan diversi;

b. Hasil kesepakatan diversi tersebut disampaikan oleh atasan Penyidik Anak/Fasilitator Diversi kepada KetuaPengadilan Negeri sesuai dengan daerah hukumnya dalam waktu paling lama 3 (tiga) hari sejak kesepakatan dicapai untuk memperoleh penetapan;

c. Ketua Pengadilan Negeri mengeluarkan Penetapan dalam waktu paling lama 3 (tiga) hari terhitung sejak diterimanya kesepakatan diversi;

d. Penetapan tersebut disampaikan kepada petugas Pembimbing Kemasyarakatan/Bapas, dan Penyidik Anak/Fasilitator Diversi dalam waktu paling lama 3 (tiga) hari sejak ditetapkan;

e. Setelah menerima penetapan tersebut Penyidik Anak/Fasilitator Diversi menerbitkan Penetapan Penghentian Penyidikan. 
Dalam hal diversi dinyatakan gagal, maka Penyidik Anak/Fasilitator Diversi membuat Berita Acara Diversi, dan wajib melanjutkan penyidikan dan melimpahkan perkara ke Penuntut Umum dengan melampirkan Berita Acara Diversi dan Laporan Penelitian Masyarakat dari petugas Pembimbing Kemasyarakatan/Bapas.

2. Tata cara dan koordinasi pelaksanaan diversi pada tahap penuntutan.

a. Setelah menerima berkas dari Penyidik Anak, maka Penuntut Umum/Jaksa Anak wajib memperhatikan berkas perkara dari Penyidik Anak dan laporan hasil penelitian kemasyarakatan (Litmas) yang telah di buat oleh petugas Pembimbing Kemasyarakatan/Bapas serta kendala yang menghambat proses diversi pada tingkat penyidikan;

b. Penuntut Umum/Jaksa Anak/Fasilitator Diversi wajib mulai mengupayakan diversi dalam waktu palinglama 7 (tujuh) hari setelah menerima berkas perkara dari Penyidik Anak;

c. Apabila pelaku maupun korban setuju untuk dilakukan diversi, maka Penuntut Umum/Jaksa Anak/Fasilitator Diversi, petugas Pembimbing Kemasyarakatan/Bapas dan Pekerja Sosial memulai proses diversi penyelesaian perkara dengan melibatkan pihak terkait;

d. Proses diversi tersebut dilaksanakan paling lama 30 (tiga puluh) hari;

e. Penuntut umum/Fasilitator Diversi membuat Berita Acara Diversi. adalah :

Dalam hal diversi dinyatakan berhasil, maka prosedur selanjutnya

a. Apabila para pihak mencapai kesepakatan, maka hasilkesepakatan tersebut dituangkan dalam bentuk kesepakatan diversi;

b. Hasil kesepakatan diversi beserta Berita Acara Diversi tersebut disampaikan oleh atasan Penuntut Umum/Jaksa Anak/Fasilitator Diversi yang bertanggung jawab kepada KetuaPengadilan Negeri sesuai dengan daerah hukumnya dalam waktu paling lama 3 (tiga) hari sejak kesepakatan dicapai untuk memperoleh penetapan;

c. Ketua Pengadilan Negeri mengeluarkan Penetapan dalam waktu paling lama 3 (tiga) hari terhitung sejak diterimanya kesepakatan diversi;

d. Penetapan tersebut disampaikan kepada petugas Pembimbing Kemasyarakatan/Bapas dan Penuntut Umum/Jaksa Anak/Fasilitator Diversi dalam waktu paling lama 3 (tiga) hari sejak ditetapkan;

e. Setelah menerima penetapan tersebut Penuntut Umum/Jaksa Anak/Fasilitator Diversi menerbitkan penetapan penghentian penuntutan.

Dalam hal diversi dinyatakan gagal, makaPenuntut Umum/Jaksa Anak/Fasilitator Diversi melimpahkan perkara ke Pengadilan dengan melampirkan Berita Acara Diversi dan laporan hasil penelitian kemasyarakatan (Litmas) dari petugas Pembimbing Kemasyarakatan/ Bapas;

3. Tata cara dan koordinasi pelaksanaan diversi pada tahap pemeriksaan di Pengadilan : 
a. Setelah menerima berkas dari Penuntut Umum/Jaksa Anak, maka Ketua Pengadilan wajib menetapkan Hakim Anak atau Majelis Hakim Anak untuk menangani perkara anak paling lama 3 (tiga) hari setelah menerima berkas perkara;

b. Setelah menerima berkas perkara, Hakim Anak wajib memperhatikan berkas perkara dan laporan hasil penelitian kemasyarakatan (Litmas) yang telah di buat oleh petugas Pembimbing Kemasyarakatan/Bapas serta kendala yang menghambat proses diversi pada tingkat penuntutan;

c. Hakim Anak/Fasilitator Diversi wajib mengupayakan diversi paling lama 7 (tujuh) hari setelah ditetapkan oleh Ketua Pengadilan Negeri sebagai Hakim yang menangani perkara anak;

d. Hakim Anak/Fasilitator Diversi yang ditunjuk selanjutnya mengeluarkan penetapan Hari Musyawarah Diversi;

e. Apabila pelaku maupun korban setuju untuk dilakukan Diversi maka Hakim Anak/Fasilitator Diversi, dengan dihadiri oleh Penuntut Umum, Penasihat Hukum, Pembimbing Kemasyarakatan/Bapas dan Pekerja Sosial, dan bila perlu dihadirkan tokoh masyarakat memulai proses diversi penyelesaian perkara dengan melibatkan pihak terkait;

f. Proses diversi tersebut dilaksanakan paling lama 30 (tiga puluh) hari;

g. Proses diversi dapat dilaksanakan di ruang khusus untuk diversi ataupun di ruang mediasi Pengadilan Negeri;

h. Hakim Anak/Fasilitator Diversi membuat Berita Acara Diversi; adalah :

Dalam hal diversi dinyatakan berhasil, maka prosedur selanjutnya

a. Apabila para pihak mencapai kesepakatan, maka hasil kesepakatan tersebut dituangkan dalam bentuk kesepakatan diversi;

b. Hasil kesepakatan diversi beserta Berita Acara Diversi tersebut disampaikan kepada Ketua Pengadilan Negeri untuk dibuat penetapan;

c. Hakim/Fasilitator Diversi melaporkan hasil diversi yang dilampirkan bersama dengan hasil kesepakatan diversi dan Berita Acara Diversi yang berhasil dilaksanakan kepada Ketua Pengadilan Negeri;

d. Ketua Pengadilan Negeri mengeluarkan penetapan mengenai hal tersebutdalam waktu paling lama 3 (tiga) hari terhitung sejak diterimanya laporan beserta Berita Acara Diversi dan hasil kesepakatan diversi;

e. Penetapan tersebut disampaikan kepada Pembimbing Kemasyarakatan dan Hakim Anak/Fasilitator Diversiyang menangani perkara dalam waktu paling lama 3 (tiga) hari sejak ditetapkan;

f. Hakim Anak/Fasilitator Diversi membuat penetapan penghentian persidangan.

Dalam hal diversi dinyatakan gagal, yang mana gagalnya Diversi tersebut dapat terjadi karena hal-hal sebagai berikut :

a. Gagal sejak awal yaitu ketika Anak/orangtua/wali/pendamping/ Penasihat Hukum menyatakan tidak setuju untuk dilakukan diversi;

b. Gagal oleh karena tidak tercapai kesepakatan diversi;gagal oleh karena 
kesepakatan diversi yang tidak dilaksanakan;

Konsekwensi dari gagalnya diversi, maka perkara dilanjutkan ke tahap persidangan, selanjutnya Hakim Anak/Fasilitator Diversi melanjutkan persidangan sesuai dengan prosedur persidangan untuk anak;

Pengawasan atas proses Diversi dan pelaksanaan kesepakatan yang dihasilkan berada pada atasan langsung pejabat yang bertanggung jawab disetiap tingkat pemeriksaan dan Pembimbing Kemasyarakatan/ Bapas, dan selama proses Diversi berlangsung sampai dengan kesepakatan Diversi dilaksanakan, Pembimbing Kemasyarakatan dan Pekerja Sosial wajib melakukan pendampingan, pembimbingan;

Seyogyanya perkara-perkara tersebut, dilakukan diversi baik pada tingkat penyidik, penuntut Umum, maupun peradilan, maka sangat meminimalisir jumlah perkara anak. Namun, apabila dilihat dari syarat administrasi yang harus dipenuhi dalam pelaksanaan diversi, yaitu sesuai dengan ketentuan Undang-undang Republik Indonesia Nomor 11 Tahun 2012 tentang Sistem Peradilan Pidana Anak, Peraturan Mahkamah Agung Republik Indonesia (Perma) Nomor 4 Tahun 2014 tentang Pedoman Pelaksanaan Diversi Dalam Sistem Peradilan Pidana Anak, dan Peraturan Pemerintah Nomor 65 Tahun 2015 tentang Pedoman Pelaksanaan Diversi dan Penanganan Anak Yang Belum Berumur 12 (dua belas) Tahun, maka diversi sama sekali sulit untuk dilaksanakan secara efektif, sehingga penanganan diversi lebih banyak yang berakhir dengan kegagalan.

Berbagai dampak negatif akibat anak bersentuhan dengan dunia peradilan dapat diminimalisir sebagai upaya untuk mewujudkan kesejahteraan anak di Kota Makassar.Selain itu, sejalan dengan teori efektivitas hukum yang dicetuskan oleh Lawrence Friedman bahwa unsurunsur sistem hukum yang mempengaruhi efektivitas hukum dalam masyarakat yakni antara lain :

a. Struktur hukum (legal structure), meliputi eksekutif, legislatif dan yudikatif serta lembaga-lembaga terkait, seperti Kepolisian, Kejaksaan, dan Pengadilan, dimana penerapan diversi di kota makassar belum dilaksanakan dengan baik oleh para aparat penegak hukum tersebut;

b. Substansi hukum (legal substance) meliputi norma, peraturan maupun undang-undang, dalam hal ini Undang-undang Republik Indonesia Nomor 11 Tahun 2012 tentang Sistem Peradilan Pidana Anak

c. Budaya hukum (legal culture) meliputi pandangan, kebiasaan maupun perilaku dari masyarakat mengenai pemikiran nilai-nilai dan pengharapan dari sistem hukum yang berlaku, dengan perkataan lain, budaya hukum itu adalah iklim dari pemikiran sosial tentang bagaimana hukum itu diaplikasikan, dilanggar atau dilaksanakan..

Penerapan keadilan restroatif dalam pelaksanaan diversi yang telah berjalan selama ini dapat dikatakan belum efektif, dan berpengaruh terhadap penanganan perkara pidana anak di Kota Makassar, oleh karena jumlah perkara pidana anak yang terjadi, dan sampai ke Pengadilan masih tergolong tinggi sejak diterapkannya diversi. Hal ini, tampak dari data yang diperoleh dari hasil penelitian sebagaimana pada tabel berikut ini : 
Tabel 1

Perkembangan Penanganan Penerapan Keadilan

Restoratif Dalam Pelaksanaan Diversi Di Kota Makassar

\begin{tabular}{|c|c|c|c|}
\hline NO & TAHUN 2014 & TAHUN 2015 & TAHUN 2016 \\
\hline DIVERSI & 15 & 18 & 27 \\
\hline TIDAK DIVERSI & 676 & 707 & 723 \\
\hline JUMLAH & 691 & 725 & 750 \\
\hline
\end{tabular}

Berdasarkan hasil penelitian tersebut, menunjukkan bahwa penerapan keadilan restoratif dalam pelaksanaan diversi di Kota Makassar masih kurang efektif. Hal tersebut dipengaruhi oleh faktor-faktor diantaranya struktur hukum (legal structure), substansi hukum (legal substance) dan budaya hukum (legal culture) masyarakat Kota Makassar.

\section{PENUTUP}

Berdasakan pembahasan terhadap penerapan keadilan restoratif dalam pelaksanaan diversi di Kota Makassar, maka dapat disimpulkan bahwa Penerapan diversi sebagai bentuk penyelesaian perkara pidana anak melalui pendekatan restorative justice di Kota Makassarkurang efektif pelaksanaannya sebagaimana yang diamanatkan dalam Undang-undang Republik Indonesia Nomor 11 Tahun 2012 tentang Sistem Peradilan Pidana Anak. Hal ini disebabkan karenaMinimnya pemahaman masyarakat tentang diversi, Penegakan hukum yang masih kurang efektif, Kondisi ekonomi yang terbatas bagi keluarga Anak dan lingkungan sosial yang buruk.

\section{DAFTAR PUSTAKA}

Bagir Banan, 2016. Restorative Justice (suatu perkenalan), IKAHI, Jakarta.

Eva Achjani Zulfa dan Indriyanto Seno Adji, 2011. Pergeseran Paradigma Pemidanaan, Lubuk Agung, Bandung.

Lilik Mulyadi, 2005. Pengadilan anak di Indonesia, Teori, Praktik dan Permasalahannya, Maandar Maju, Bandung.

Maidin Gultom, 20 10. Perlindungan Hukum Terhadap Anak Dalam Sistem Peradilan Pidana Anak di Indonesia, Refika Aditama, Bandung.

Marlina.2009. Peradilan Pidana Anak di Indonesia, Pengembangan Konsep Diversi dan Restorative justice, Refika Aditama Bandung.

. 2010. Pengantar Konsep Diversi dan Restorative Justice dalam Hukum Pidana, USU Press, Medan.

Mursyid, M. 2019. Implementation of Human Rights Protection Towards in 
Penitentiary of Children in Makassar. Substantive Justice International Journal of Law, 2(1), 71-88.

Sri Sutatiek. 2012. Konkretisasi Pendekatan Keadilan Restoratif (Restorative Justice) Melalui Diversi Oleh Hakim Anak di Pengadilan Negeri, Ikatan Hakim Indonesia, Jakarta. 